\title{
RPD
}

\section{RESIDENTS' ATTITUDES TOWARDS TREE CARE PROGRAMS IN CITYSCAPES}

\author{
Oghenekevwe Joy Arabomen (https://orcid.org/0000-0002-1309-3328) ${ }^{1 *}$ \\ Folaranmi Dapo Babalola (https://orcid.org/0000-0002-8837-0991) ${ }^{2}$ \\ Felix Oaikhena Idumah (https://orcid.org/0000-0001-8979-9290) ${ }^{1}$ \\ Chinyere Salome Ofordu (https://orcid.org/0000-0001-9794-0901) ${ }^{1}$
}

1. Forestry Research Institute of Nigeria, P.M.B.5054, Jericho hill, Ibadan, Nigeria

2. Department of Forest Resources Management, University of Illorin, Nigeria

* oarabomen14@gmail.com

\section{Submitted: 15/12/2020. Accepted: 17/03/2021}

Published:22/03/2021

\begin{abstract}
Purpose: Examine residents' attitude towards urban trees from the perspective of funding or voluntarily contributing time for tree care programs. Majority of global populace live in cities, hence, the rise in public expectations for liveable, sustainable and greener communities and urban areas all over the world, Nigeria inclusive. With proper planning and management, cities may become more liveable, but the rapid loss of large urban green areas cause havoc, and has ushered in several problems such as adverse climatic condition, reduced water and air quality, amongst others.
\end{abstract}

Metodology: A questionnaire survey was conducted to understand how residents rank and rate the benefits of urban trees as well as individual willingness to support conservation initiatives, using Benin metropolis, Nigeria as a case study.

Findings: Using binary logit analysis, the study identified that residents who are aware of ecosystem services, had a profession and have spent at least 20 years in the city, had a significant relationship with personal willingness to volunteer time and/or donate money toward urban tree care programs and activities.

Contribution to knowledge: Provided quantitative information to demonstrate the importance of conserving trees in development projects towards Global SDGs.

Keywords: biophysical resource, market survey, land use, urban forests, sustainable development goals

\section{ATITUDES DOS RESIDENTES COM OS PROGRAMAS DE PROTEÇÃO DE ÁRVORES EM PAISAGENS URBANAS}

\section{RESUMO}

Objetivo: Examinar a atitude dos residentes em relação às árvores urbanas a partir da perspectiva de financiamento ou contribuição voluntária de tempo. A maioria da população global vive em cidades, daí o aumento na expectativa por comunidades habitáveis, sustentáveis e mais verdes, inclusive na Nigéria. Com planejamento e gestão adequados, as cidades podem se tornar mais habitáveis, mas a rápida perda de grandes áreas verdes urbanas causa estragos e tem levado a vários problemas climáticos, redução da qualidade da água e do ar, entre outros.

Metodologia: Uma pesquisa por questionário buscou entender como os residentes avaliam os benefícios das árvores, bem como a vontade individual de apoiar iniciativas de conservação, tendo a metropole de Benin (Nigéria) como estudo de caso.

Resultados: Usando a análise logit binária, o estudo identificou que os residentes que estão cientes dos serviços do ecossistema, tinham uma profissão e passaram pelo menos 20 anos na cidade, tiveram uma relação significativa com a vontade pessoal de oferecer tempo voluntário e / ou doar dinheiro para programas urbanos para o cuidado das árvores.

Contribuição para o conhecimento: Forneceu informações quantitativas para demonstrar a importância da conservação de árvores em projetos de desenvolvimento para atender aos ODS Globais.

Palavras-chave: recurso biofísico, pesquisa de mercado, uso da terra, florestas urbanas, sustainable development goals. 


\section{INTRODUCTION}

Urban tree management as a discipline is a relatively new field that is fast gaining prominence in Africa, Nigeria inclusive. The research on urban trees has been extensively reported in literature. For instance, Venter et al. (2020), Yeshitela (2020), Aladesanmi et al. (2017), Agbelade et al. (2016), Goodness and Anderson (2013) and McConnachie and Shackleton (2010) examined the distribution of urban trees as an ecosystem approach to planning and managing green spaces in major cities of South Africa. Mpofu (2013) evaluated land use and land cover change and the various challenges facing the management of trees in Addis-Ababa. Djibril et al. (2012) described the benefits of trees and green spaces in Abidjan City, Ivory Coast. Anchang et al. (2016) reported mapping of vegetation and green spaces using satellite imagery for areas with technical and financial constraints. Notably, these studies have indicated the potential of urban trees to contribute significantly to healthiness and environmental quality in urban areas. Moreover, mature trees can help a city meet the Sustainable Development Goals, particularly, Goal 11 (Sustainable Cities), 13 (Climate Action) and 15 (Life on Land), through providing access to safe green areas, improving the quality of life for people living in cities and ensuring sustainable development worldwide by 2030 .

However, with a projected 1.3 billion people living in cities across Africa by 2050, if the Sustainable Development Goals are to be met, there must be adequate planning and management in place for the rapidly rising urban population (United Nations 2015a; UN-Habitat 2014). Similarly, Aina and Salau (2012) observed some of the major impediments to sustainable economic development of urban trees in Nigeria, to include the unavailability of effective "resource pricing" instruments for conservation and protection of nature. Given the heavy dependence on tree resources in Africa, many cities are vulnerable to the rapid loss of trees through conversion for construction of roads, social amenities, buildings and to other land allocation priorities. Moreover, urban trees are disappearing at alarming rates in African cities. This hampers urban residents' access to green spaces and green areas that are essential components of the liveability of cities (Mensah, 2014; Olaleye et al., 2013; Djibril et al., 2012). Thus, effective measures to protect and, preferably, restore already lost urban trees, and the ecosystems they form part of, must urgently be put in place.

This study explored the contribution of a sustainability model (Clark and Matheny 1998) to urban tree development, and most importantly their contribution to sustenance of ecosystem services in urban areas. The conceptual framework was premised on the fact that sustaining urban trees entails the interaction of a healthy tree resource, public support and personal involvement and continued funding. The aim of this study was to examine residents' attitude towards urban trees from the perspective of funding or voluntarily contributing time for tree care programs.

The research questions and objectives addressed were as follows:

(1) What are residents' attitude towards urban trees and tree care programs?

(2) What benefits do residents associate with urban trees?

(3) Are residents' willing to give time or donate money for tree care programs?

(4) Does individual socio or demographic factors influence or hinder their participation?

Findings from this study could provide current and accurate data for urban managers towards promoting sustainable management of trees in developing African cities and/or elsewhere.

In addition to this introduction, the study presents a literature review section that presents themes that support the theme explored by this study, as well as seeks to present a state of knowledge that seeks to provide thematic support on questions about Metropolitan areas and towns, and need trees and green spaces. A methodology section is also presented. The results and conclusions of this work are presented below. 


\section{LITERATURE REVIEW}

Metropolitan areas and towns need trees and green spaces. The network of clusters and/or individual trees in a metropolis and on its peripheries provide so many services like other types of city infrastructure- such as climate modification, improved air quality, reduced flooding and erosion, improved physical and mental health of citizens, habitat for wildlife, enhanced social cohesion, recreation opportunities, and they may even reduce crime. These values enhance the look of cities and are reflected in higher property values, energy savings, an inflow of tourists and other people and businesses (Zhang et al., 2017). Notably, these evidence have shown that green infrastructure could strengthen community growth and dynamics (Clark et al., 2018). On the other hand, these trends in economic activity reflects a change in public value for trees and natural environment. For instance, the human population in the conterminous United States is rapidly growing and expanding from core areas into the fringes, in search of green spaces and associated facilities. Additionally, markets such as credits for carbon sequestration and ecotourism have developed for ecosystem services from trees. Therefore, urban trees play a crucial role in sustainable development, with the goal to make cities and communities liveable, resilient and healthy for society at large (Konijnendijk 2018).

Globally, urban growth will continue for coming decades. Small villages will develop to townships, towns will evolve to metropolises, and metropolises will become megacities. In Nigeria, for example, towns and cities are growing rapidly. However, this rapid growth rate does not compliment the proportion at which forest and trees are preserved (Oguntala 2013). This is because the tree is being cleared for developmental purposes and in some cases, for its timber component. Additionally, trends of loss of trees have been recorded in some major cities of Nigeria usually from interplay of several factors including industrial expansion, construction activities, population growth and increasing demands for fire wood (Ajewole 2015; Ajayi 2005; Oguntala 2013; NEST 2001; Odermerho 1988; Ogigirigi 1986). Urban sprawl has led to the conversion of green spaces for the development and construction of roads, housing, infrastructural facilities, social amenities and other land allocation priorities (Arabomen et al., 2020). Huang (2014), reiterated that rapid economic development and sprawl of residents in cities of China has led to undue land changes and decline of the natural environment. Globally, the consequence of urbanization has been a deterioration in the quality of life and the environment of cities. Thus, ensuring both liveable and sustainable cities is a universal challenge to which urban forestry professionals and other relevant stakeholders must rise. Moreover, the international community and the United Nations have recognized that rapid, unplanned urban sprawl could drive health related issues amongst other challenges as new cities continue to evolve.

Urban tree programs involving community participation have emerged as a new concept and approach to enhance sustainable management of forest resources in cities. Although, still at its infancy alongside initiatives for other public infrastructure, tree care programs have over the past decade contributed positively to management for the provision of ecosystem services (Landel-Mills and Porras 2012; Simpson and Sedjo 2016). Recent trends in the study of urban forest management is observed to be heading in a more people-oriented direction since after the Brundtland Report of 1987 and the Rio 1992 Earth Summit (Sanderson and Redford 2013). The Brundtland Commission Report of 1987 have for decades served as the platform for discussing sustainable systems defined as "forest management to meet the needs of present society without compromising the capacity to meet future needs". This will be achieved through active land stewardship ethics that involves growing, nurturing and harvesting of forest and trees for its products while conserving biodiversity as well as community cooperation, personal involvement and funding. However, many people are not aware of the need for effective participation and monetary support. This is because most community tree care programs are either not well established or overlooked. In addition, the "free rider" nature of trees and their benefits is often a source of market failure. Consequently, conservation programs often faced with inconsistent and unsustainable support from stakeholders 
including government (at all levels), individuals, private organizations, NGOs, amongst others. Thus, information on public attitudes could drive many aspects including fund allocation, financing, people's involvement, incorporation of tree programs into cityscapes, and community preference or values that could assist in developing adaptable and sustainable management strategies for urban trees (Zhang et al., 2017b).

Conversely, literature methodically described a model for assessing a community's progress towards this goal (Clark and Matheny 1998). This region-independent and quantitatively based model provides basic principle for assessing urban trees within the central view that sustaining healthy urban trees would require community support and effective management approach. Thus, the conceptual framework of this study was based on the community-management framework (adopted from Clark and Matheny 1998) which highlights significant steps for involvement of people towards promoting sustainable management of urban trees. On the one hand, in the Community approach - people share a common idea for trees as a public resource and work to actualize it through defined goals and objectives. Community approach was expanded to include attitude towards trees and ecosystem services to reveal the important role that processes, such as knowledge, information, benefit of trees and local management initiatives could play in supporting community approach towards a sustainable tree management. On the other hand, the Management approach assessed individual cooperation and support through sharing the financial burden to cater for urban trees especially where there is reduced government service to protect urban landscapes for both present and future benefits. Funding was considered with focus on willingness to donate money for tree care programs. This was holistic in considering how this could contribute to sustaining urban trees.

Therefore, this study was designed to use indigenous knowledge obtained through field observation, questionnaire survey and interviews to analyse the attitudes of residents on urban trees and tree care programs using a rapidly developing metropolis in Nigeria as a case study. Findings from this seminal study could assist in developing an assessment tool that could enhance adequate monitoring and management plans for the urban trees and green areas in major cities in Nigeria and/or elsewhere.

\section{MATERIAL AND METHODS}

\subsection{Brief information of the study area}

Benin metropolis in Southern Nigeria is in a land area of $1204 \mathrm{~km}^{2}$. It is the $4^{\text {th }}$ largest metropolitan center in the country with an estimated 1495800 inhabitants (NPC 2016). Administratively, the metropolis has three Local Management Zones (LMZs) and 39 wards namely: Egor (10), Ikpoba-Okha (11) and Oredo (18). The geographical coordinate is located between Latitudes $6^{\circ} 10^{\prime} 6^{\circ} 30^{\prime} \mathrm{N}$ and Longitude $5^{\circ} 30^{\prime} 5^{\circ} 45^{\prime} \mathrm{E}$. The mean temperature is about $25^{\circ} \mathrm{C}$ daily. The metropolis has two distinct seasons: a wet period from March to July with a break in August and a dry season from November to February. The predominant vegetation is the moist deciduous forest consisting of native and introduced trees. Owing to its biological importance, there are diverse and rich flora in areas such as flora gardens, avenues, open spaces, roadsides, institutions and residences (Arabomen et al., 2019; 2020).

\subsection{Sampling procedure}

Multistage sampling was used to obtain the primary data needed. The LMZs of Egor, Ikpoba-Okha and Oredo was the first stage. The second stage were the wards. In the third stage, 350 residents were randomly selected i.e., without considering any specific characteristic. Socio survey was conducted in twenty-seven (27) sites, representing $70 \%$ of the total number of wards and nine (9) in each LMZs in Benin metropolis. The survey was conducted between June and November 2017. Prior to data collection, reconnaissance survey was done to obtain background information 
and mapping out of study area. In addition, a pre-test of $10 \%$ of the total number of the questionnaire was done to ensure its validity and reliability. The outcome of this, combined with a review of relevant literature contributed to final questionnaire development and interpretation of study results. This section of the study has been modified from past studies (see Arabomen et al., 2019; 2020).

\subsection{Data collection}

Self-administered questionnaires were completed and returned immediately by the 350 residents. The questionnaire consisted of enquiries relating to the following: (a) cognition of respondents on having mature trees on their personal property (b) attitude of residents on the presence of trees on the city landscape (c) perceived ecosystem benefits people associate with trees (c) support for urban tree care programs (d) acceptance of conservation measures (e) willingness to volunteer time and/or donate money for tree care programs (see Tables 2 and 3 for exact phrase and description in the questionnaire). Individual responses were rated on a Likert-point scale of 1 (not important/not likely) to 3 (very important/most likely). The use of 3 groups is not uncommon in same types of studies (see Zhang 2017; Lohr et al., 2004). This was to increase the sharpness of the comparison owing to the low scores of some variables. In addition, seven (7) socio and demographic measures - location, gender, marital status, length of stay, education, occupation, and family size - were used to describe residents in the study area.

\subsection{Statistical analysis}

Overall, 325 (93\% response rate) valid questionnaires were coded for the analysis. 25 questionnaires were discarded due to irregularities and omitted information. Descriptive statistics i.e. frequencies were performed on categorical variables and summary statistics were done on continuous variables to describe the attitude of respondents on trees and tree care activities. Furthermore, binary logistic regression was used to determine which explanatory variables influenced people's willingness to support tree care programs in the area. This model provided a suitable fit for binary choice situations in which the dependent variable can assume only two values (Resende et al. 2017; Hill et al., 2006; Loomis et al., 2000). In this study, the dependent variable i.e. the willingness of a respondent to give time or donate money, assumed a value of " 1 " if "yes" and " 0 " if "no". This was evaluated as a function of several categorical and explanatory variables including: gender (female $=1$; male $=2)$, marital status $(1=$ married; $2=$ unmarried $)$, education (none $=1$; college $=2$; undergraduate $=3$; postgraduate $=4$ ), occupation (paid jobs $=1$; trading $=2$; business owners $=3$; unemployed $=4)$, length of stay categorized as $(<10=1 ; 10-20=2 ; 21-30=$ $3 ; 31-40=4$ ), knowledge of benefits (no knowledge $=0$; prior knowledge $=1$ ). If $p \leq 0.05$ value was observed, it was concluded that the explanatory variable had a significant effect on the dependent variables. This section of the study has been modified from past studies (see Arabomen et al., 2019; 2020).

\section{RESULTS AND DISCUSSION}

\section{Respondents' socio and demographic profile}

Overall, $31 \%, 33 \%$ and $36 \%$ of the respondents were living respectively in Egor, IkpobaOkha and Oredo LMZs (Table 1). These were mostly men $(56 \%-70 \%)$ and very few $(33 \%)$ single people across the LMZs (Table 1). Most of the residents had lived in the city for at least 21 years. In this survey, $68 \%$ had five or more relatives as household members. The literacy level was quite high considering that only few (10\%) people had no basic formal education. Additionally, most $(75 \%)$ of the respondents were employed on paid jobs or trading. 
Table 1: Descriptive statistics of respondents' socio and demographic profile

\begin{tabular}{|c|c|c|c|}
\hline $\begin{array}{l}\text { Sociodemographic } \\
\text { measure }\end{array}$ & Definition & Mean & Std. Error \\
\hline LMZs & 1= Egor, $2=$ Ikpoba-Okha, $3=$ Oredo & 2.046 & 0.045 \\
\hline Gender & binary, $1=$ female, 2 if otherwise & 1.557 & 0.027 \\
\hline Marital status & binary, $1=$ married, 2 if otherwise & 1.332 & 0.026 \\
\hline Occupation & $\begin{array}{l}1=\text { resident has a paid job, } 2=\text { resident is a trader, } 3= \\
\text { resident is unemployed }\end{array}$ & 1.886 & 0.042 \\
\hline Family size & $\begin{array}{l}1=\text { family size is }<5,2=\text { family size is } 5-9,3=\text { family } \\
\text { size is } \geq 10\end{array}$ & 1.889 & 0.040 \\
\hline Literacy level & $\begin{array}{l}1=\text { resident has attended a graduate school, } 2= \\
\text { resident has a } 4 \text {-year degree, } 3=\text { resident has a high } \\
\text { school degree, } 4=\text { resident is not educated }\end{array}$ & 2.274 & 0.054 \\
\hline Length of stay & $\begin{array}{l}1=<10 \text { years, } 2=10-20 \text { years, } 3=21-30 \text { years, } 4= \\
31-40 \text { years }\end{array}$ & 2.996 & 0.051 \\
\hline
\end{tabular}

\section{Residents' attitude toward urban trees and ecosystem services}

Considering the reality of urbanization pressures on urban trees in Africa, it is imperative to apply indigenous knowledge in determining public attitude on trees and the ecosystem services rendered by urban trees. Based on survey responses, most Benin residents had a positive affinity for urban trees in the environment (Table 2). For instance, most (96\%) of the residents highlighted the importance of urban trees for the provision of regulating services. Some of these regulating services include climate modification, beautifying the landscape, mitigating flooding and erosion and provision of shade and cooling of the urban environment. However, other services such as provision of fruits, spiritual and medicinal value though mentioned, were considered not important. Interestingly, the residents indicated that urban trees played a very important role in their decisions on where to live. Most (93\% - 95\%) of the people said trees are important in choosing a residential location in particular, or in general, a community to live in (Table 2).

Table 2: Summary of residents' attitude toward urban trees and ecosystem services

\begin{tabular}{|c|c|c|c|}
\hline \multirow[t]{2}{*}{ Attitude measure $^{t t}$} & \multicolumn{3}{|c|}{ Proportion of respondents $(N=325)$} \\
\hline & Not important & Don't Know & Very important \\
\hline $\begin{array}{l}\text { Importance of having trees on property } \\
\text { when choosing a place to live }\end{array}$ & $10(3.08)$ & $8(2.46)$ & $307(94.5)$ \\
\hline $\begin{array}{l}\text { Importance of having tree canopy in the } \\
\text { community environment }\end{array}$ & $14(4.31)$ & $8(2.46)$ & $303(93.3)$ \\
\hline $\begin{array}{l}\text { Importance of having trees for the } \\
\text { multiple benefits they provide }\end{array}$ & $11(3.39)$ & $2(1)$ & $312(96.1)$ \\
\hline $\begin{array}{l}\text { Importance of having trees for erosion } \\
\text { and flood control }\end{array}$ & $12(3.69)$ & $18(5.54)$ & $295(90.77)$ \\
\hline $\begin{array}{l}\text { Importance of having trees for the } \\
\text { beautiful scenery they give a city }\end{array}$ & $14(4.31)$ & $6(1.85)$ & $305(93.85)$ \\
\hline $\begin{array}{l}\text { Importance of having trees to help } \\
\text { regulate temperature }\end{array}$ & $5(1.54)$ & $2(1)$ & $318(97.85)$ \\
\hline $\begin{array}{l}\text { Importance of having trees for the fruits } \\
\text { or food they provide }\end{array}$ & $316(97.2)$ & $9(2.77)$ & $0(0)$ \\
\hline $\begin{array}{l}\text { Importance of having trees for the } \\
\text { medicinal values }\end{array}$ & $318(97.85)$ & $3(1)$ & $4(1.24)$ \\
\hline $\begin{array}{l}\text { Importance of having trees for their } \\
\text { shade }\end{array}$ & $7(2.15)$ & $1(0)$ & $317(97.6)$ \\
\hline $\begin{array}{l}\text { Importance of having trees for their } \\
\text { spiritual values }\end{array}$ & $310(95.4)$ & $15(4.62)$ & $0(0)$ \\
\hline
\end{tabular}

\footnotetext{
${ }^{\dagger \dagger}$ Rounding may result in numbers adding to $\geq 100 \%$

results in parentheses ( ) are in percentages
}

Several studies have reported the regulating services of urban trees in cities. For instance, in Kumasi, Ghana, aesthetics, shade and temperature reduction were the highest ranked benefits 
(Dumenu, 2013). Roberts et al. (2012) highlighted the importance of urban trees in climate change mitigation and reducing the impacts of natural hazards such as flooding. Other studies indicated the important role of urban trees in temperature regulation in Addis Ababa, Ethiopia; Dar es Salaam, Tanzania; and Bobo-Dioulasso, Burkina Faso (Di Leo et al., 2016; Cavan et al., 2014; Feyisa et al., 2014). In addition, citizens of the United Kingdom and United States indicated that trees were highly valued elements and that their benefits far outweigh their disservices (Schroeder et al., 2006). Thus, the findings of previous studies, and the result from this study show a growing awareness of the intrinsic benefits of urban trees in African cities. In essence, it would be of great significance to intensify education campaigns about urban trees that could emphasize on the numerous services provided by urban trees to enhance conservation measures designed to protect trees and sustenance of ecosystem services in Benin metropolis and/or elsewhere.

\section{Residents' attitude toward urban tree care activities}

An important aspect of this study was to investigate public attitudes toward supporting local community tree care activities from a variety of perspectives. Several reports have demonstrated and acknowledged that sustaining urban forests cannot be separated from the actions of humans, as such actions can be both positive and adverse. In the latter case, creation and maintenance of urban infrastructure can be extremely destructive such that cities are superimposed atop urban trees. The greater the imposition, the less natural the urban tree ecosystem appear and function (Nowak et al., 2016). On the other hand, the adverse impacts of humans can be mitigated by corresponding positive actions such as planning, planting and management. Thus, in this study, people's attitudes toward supporting local conservation activities were positive in terms of giving time and/or contributing money (Table 3). However, most (98\%) respondents were more likely to volunteer time and engage in tree care programs. The respondents wished, but in decreasing order, trainings on good management practices (17\%), discouraging the removal of existing trees (33\%), public sensitization campaigns (95\%), and tree planting $(96 \%-97 \%)$ would proffer collective efforts to enhance the conservation of urban trees in cities.

Table 3: Residents' attitude toward tree care activities

\begin{tabular}{lccc}
\hline Attitude measure & \multicolumn{2}{c}{ Proportion of respondents $(\boldsymbol{N}=325)$} \\
\cline { 2 - 4 } & Unlikely & Don't Know & Very likely \\
\hline $\begin{array}{l}\text { How likely would you volunteer time } \\
\text { for tree care activities }\end{array}$ & $6(1.85)$ & $2(1)$ & $317(97.5)$ \\
$\begin{array}{l}\text { How likely would you donate cash } \\
\text { money for tree care programs }\end{array}$ & $14(4.31)$ & $8(2.46)$ & $289(88.9)$ \\
$\begin{array}{l}\text { How likely would you engage in } \\
\text { planting more trees }\end{array}$ & $8(2.46)$ & $2(1)$ & $315(96.92)$ \\
$\begin{array}{l}\text { How likely would you encourage } \\
\text { family and friends to plant trees }\end{array}$ & $8(2.46)$ & $5(1.54)$ & $312(96.1)$ \\
$\begin{array}{l}\text { How likely would you discourage } \\
\text { uncontrolled removal of existing trees }\end{array}$ & $43(13.23)$ & $66(20.31)$ & $108(33.24)$ \\
$\begin{array}{l}\text { How likely would you participate in } \\
\text { public sensitization campaigns }\end{array}$ & $5(1.54)$ & $12(3.69)$ & $308(94.77)$ \\
$\begin{array}{l}\text { How likely would you accept trainings } \\
\text { on good management practices }\end{array}$ & $262(80.62)$ & $9(2.77)$ & $54(16.62)$ \\
\hline
\end{tabular}

${ }^{\mathrm{y}}$ Rounding may result in numbers adding to $\geq 100 \%$

Results in parentheses ( ) are in percentages

Creation and management of urban forests and trees to achieve sustainable management is the long-term goal of urban foresters, as well as public and private entities including government and citizens (Clark and Matheny 1998). Moreover, literature has stressed that public participation has the potential to enhance sustainable management of tree resources for the numerous benefits in cities (Simpson and Sedjo 2006). Bearing in mind that urban trees are distributed among all private and public lands such as universities, business parks, corporate campuses, commercial real estates, 
avenues, streets, roadsides, open spaces, residences, botanical gardens inter alia, the success of any effort at sustainability must include the people who live in and around them, i.e. public participation and commitment. The implications of this is far-reaching. First, urban trees require active, consistent, continuing management, since the accrual of net benefits can only occur when adequate and reasonable care is provided. Second, urban forest managers, city planners and government must involve residents in urban areas in decisions and actions regarding urban trees. In essence, this study suggests that translating residents' willingness to voluntarily participate in conservation initiatives into action would be essential for creating sound and effective conservation measures of urban trees in cities. Furthermore, it is worth mentioning that in this study we did not include information on the amount people were willing to donate either as open or closed ended questions. This concern was addressed in our previous report (see Arabomen et al., 2019) with more properly designed methodology.

\section{Factors explaining respondents support for tree care programs}

Many socio-economic variables have been reported to significantly influence willingness of local people to contribute time or money for conservation of urban green spaces (Dumenu 2013; Adekunle et al., 2013). As a result, a binary logit statistic was used to determine the relationship between the willingness of an individual to donate time or money for conservation of urban trees across selected socio-demographic (education, marital status, years of residency, profession and gender) and attitude variable (awareness of benefits). Only the statistics value with variables significant at the 0.05 or 0.01 level are shown in Table 4 . The results corresponding to the willingness to donate time and money showed that knowledge of tree benefits, having a paid job or trading business, being in the city for more than 20 years, and education increased the probability of donating time or money to community forestry activities. Other socio-demographic factors commonly related to public participation (e.g. location, gender, family size, marital status) were consistently insignificant. However, the only difference observed pertained to the significance of the variable "having a formal education or at least a high school education", which was significant only in the willingness to volunteer time analysis.

Table 4: Result for binary logistic analysis (Number of observations $=325$ )

\begin{tabular}{|c|c|c|c|c|c|c|c|}
\hline \multirow[t]{2}{*}{ Measure } & \multirow[t]{2}{*}{ Meaning } & \multicolumn{3}{|c|}{$\begin{array}{c}\text { Willingness to contribute } \\
\text { money }\left(\mathrm{y}_{1}\right)\end{array}$} & \multicolumn{3}{|c|}{$\begin{array}{c}\text { Willingness to volunteer } \\
\text { time }\left(\mathrm{y}_{2}\right)\end{array}$} \\
\hline & & $\mathrm{EXP}(\mathrm{B})$ & Wald & $P$-value & $\operatorname{EXP}(\mathrm{B})$ & Wald & $P$-value \\
\hline Constant & & & 0.448 & & & 3.993 & \\
\hline$\left(\mathrm{x}_{1}\right)$ Paid job individuals & $1=$ yes, 0 otherwise & 3.064 & 1.564 & 0.033 & 1.472 & 3.987 & 0.045 \\
\hline$\left(\mathrm{x}_{2}\right)$ Trading & $1=$ yes, 0 otherwise & 1.582 & 1.201 & 0.051 & & & \\
\hline$\left(\mathrm{x}_{3}\right)$ High school & $1=$ yes, 0 otherwise & & & & 0.106 & 1.774 & 0.018 \\
\hline $\begin{array}{l}\left(\mathrm{x}_{4}\right) \text { Length of residency 21-30 } \\
\text { years }\end{array}$ & $1=$ yes, 0 otherwise & & & & 1.298 & 1.537 & 0.021 \\
\hline $\begin{array}{l}\left(x_{5}\right) \text { Length of residency 31-40 } \\
\text { years }\end{array}$ & $1=$ yes, 0 otherwise & 1.273 & 4.421 & 0.051 & & & \\
\hline $\begin{array}{l}\left(\mathrm{x}_{6}\right) \text { Vital to have trees on } \\
\text { property when choosing a home }\end{array}$ & $1=$ yes, 0 otherwise & 1.333 & 2.286 & 0.001 & 3.065 & 3.164 & 0.051 \\
\hline$\left(\mathrm{x}_{7}\right) \mathrm{I}$ am aware of tree benefits & $1=$ yes, 0 otherwise & 1.029 & 1.291 & 0.043 & 3.180 & 3.269 & 0.045 \\
\hline Log likelihood function & 221.568 & & & & & & \\
\hline $\begin{array}{l}\text { Chi squared } \\
\text { Prob. } \\
\text { [Chi squared > value] }\end{array}$ & $\begin{array}{l}16.933 \\
0.000 * *\end{array}$ & & & & & & \\
\hline $\begin{array}{l}\text { Cox and Snell } R^{2} \\
\% \text { correctly predicted }\end{array}$ & $\begin{array}{l}0.051 \\
88\end{array}$ & & & & & & \\
\hline
\end{tabular}

$\mathrm{p} \leq 0.05$ or 0.01 , based on logistic function 
Public participation for forestry related activities is particularly important in strengthening the position of the green infrastructure in the political agenda of public administrations and gaining more support for the planning, development and management (Schwab 2009; Wolf 2004). Although the factors identified in table 4 above may not be used to make inferences for the entire Benin metropolis, the results suggest some specific ways in which peoples' demographics may contribute to variation in attitude and cognition toward trees in cities. Thus, concerted efforts to encourage the sustainable management of trees would be more effective if communication on management is designed to suit relevant sociodemographic status of residents in the metropolis. Simultaneously, this would assist to motivate people to actively participate in or even pay for tree conservation and management programs (Arabomen et al., 2019).

\section{CONCLUSION}

Given the overall physiognomies of sustainable systems and the explicit nature of urban forests, this study, based on the findings, has contributed to the body of knowledge on the application of a sustainability model (Clark and Matheny 1998) towards promoting conservation initiatives of urban trees and sustenance of ecosystem services in cities. Currently, the global world is grappling with unprecedented and rapid urbanization which among others put strains on the urban landscape. Consequently, this leads to landscape fragmentation, biodiversity loss, loss of ecosystem services and impaired functional productivity of city spaces.

Moreover, sustainable development which is multidisciplinary in nature, now than ever, requires a contemporary scientific knowledge that could facilitate the attainment of the Sustainable Development Goals, particularly goals 11,13 and 15 towards proffering realistic solutions to improve the living conditions of people in cities. This requires research aimed at understanding the role of urban dwellers in promoting sustainable cities, which in turn could enhance urban liveability. Therefore, this study was conducted to use indigenous knowledge to analyse the attitudes of residents on urban trees and tree care programs using a rapidly developing metropolis in Nigeria as a case study. The study adopted a social framework (Clark and Matheny 1998) including two principal criteria of community and management approach as a guide to assess information on the attitude of residents towards urban trees in Benin metropolis, Nigeria.

Notably, this research addressed an important aspect of how integrating and understanding the socio-economic components, awareness of ecosystem services and willingness to contribute time or even donate money for tree care activities could offer contextual insights into promoting management strategies for urban trees in cities. However, further research could be carried out on other values, i.e. cultural, that could promote sustainability of urban trees in cities. Most importantly, this study provided fundamental step towards fostering urban dwellers support towards greening of metropolitan landscapes. Using Benin metropolis as a case study, this research therefore recommends public involvement in conservation initiatives at community level, town planners, government and forest resource managers' involvement, as critical to reducing challenges facing the conservation of urban trees at the core and periphery of the Metropolis in particular, and other cities globally.

\section{REFERENCES}

Adekunle, M., Agbaje, B and Kolade, V. (2013). Public perception of ecosystem service functions of peri - urban forest for sustainable management in Ogun State. African Journal of Environmental Science and Technology, 7(6), 410-416. https://doi.org/10.5897/ajest2012.1411

Agbelade, A.D., Onyekwelu, J.C and Apogbona, O. (2016). Assessment of urban tree species population and diversity in Ibadan, Nigeria. Environmental and Ecology Research, 4(4), 185-192. https://doi.org/10.13189/eer.2016.040401

Aina, T. A., \& Salau, A. T. (1992). Challenge of sustainable development in Nigeria. NEST, Ibadan, NG. 
Ajayi, P.O. (2005). Socio-economic losses arising from the destruction of Ibadan urban fuelwood plantations. MSc Dissertation, Department of Forest Resource Management, University of Ibadan, Nigeria. 106.

Ajewole, O.I. (2015). Public willingness to commit time to urban forestry development in Lagos metropolis, Nigeria. Agriculture and Social Research, 15(1), 46-68.

Aladesanmi, D.A., Jonathan, C.O and Matthew, B.O. (2017). Tree species richness, diversity, and vegetation index for Abuja, Nigeria. International Journal of Forestry Research. 12.

Anchang, J.Y., Ananga, E.O and Pu, R. (2016). An efficient unsupervised index-based approach for mapping urban vegetation from IKONOS imagery. International Journal of Applied Earth Observation and Geoinformation, 50, 211220. https://doi.org/10.1016/j.jag.2016.04.001

Arabomen, O., Chirwa, P.W and Babalola, F.D. (2019). Willingness-to-pay for environmental services provided by trees in core and fringe areas of Benin City, Nigeria. International Forestry Review, 21(1), 23-36. https://doi.org/10.1505/146554819825863717

Arabomen, O., Chirwa, P.W and Babalola, F.D. (2020). Understanding public willingness to participate in local conservation initiatives of urban trees in Benin City, Nigeria. Arboriculture and Urban Forestry, 46(4), $247-261$. https://doi.org/10.48044/jauf.2020.018

Cavan, G., Lindley, S., Jalayer, F., Yeshitela, K., Pauleit, S., Renner, F., et al. (2014). Urban morphological determinants of temperature regulating ecosystem services in two African cities. Ecological Indicators, 42, 43-57. https://doi.org/10.1016/j.ecolind.2014.01.025

Clark, J.R and Matheny, N.P. (1998). A model of urban forest sustainability: application to cities in the United States. Arboriculture and Urban Forestry, 24(2), 112-120.

Clark, T.N., Iloyd, R.,Wong, K and Jain, P. (2018). Amenities drive urban growth. Journal of Urban Affairs, 24(5), 493515. https://doi.org/10.1111/1467-9906.00134

Di Leo, N., Escobedo, F.J and Dubbeling, M. (2016). The role of urban green infrastructure in mitigating land surface temperature in Bobo-Dioulasso, Burkina Faso. Environment, Development and Sustainability, 18, $373-392$. https://doi.org/10.1007/s10668-015-9653-y

Djibril, K., Coulibaly, A., Wang, X and Ousmanes, D. (2012). Evaluating green space use and management in Abidjan City, Cote d'Ivoire. International Journal of Economics and Management Engineering, 2(3), 108-116.

Dumenu, W.K (2013). What are we missing? economic value of an urban forest in Ghana. Ecosystem Services, 5, 137142. https://doi.org/10.1016/j.ecoser.2013.07.001

Feyisa, G.L., Dons, K and Meilby, H. (2014). Efficiency of parks in mitigating urban heat island effect: An example from Addis Ababa. Landscape and Urban Planning, 123, 87-95. https://doi.org/10.1016/j.landurbplan.2013.12.008

Goodness, J and Anderson, P. L. (2013). Local assessment of Cape Town: navigating the management complexities of urbanization, biodiversity, and ecosystem services in the cape floristic region. In: urbanization, biodiversity and ecosystem services: challenges and opportunities (T. Elmqvist, M. Fragkias, J. Goodness, B. Güneralp, P.J. Marcotullio, R.I. McDonald, S. Parnell, M. Schewenius, M. Sendstad, K. C. Seto, C. Wilkinson, eds.), Springer Netherlands. 461484. https://doi.org/10.1007/978-94-007-7088-1_24

Huang, S.L. (2014). Park user preference for establishing a sustainable forest park in Taipei, Taiwan. Urban Forestry and Urban Greening, 13(4), 839-845. https://doi.org/10.1016/j.ufug.2014.10.002

Konijnendijk, C.C., Sadio, S., Randrup, T.B and Schipperijn, J. (2018). Urban and peri-urban forestry in a development context-strategy and implementation. Arboriculture and Urban Forestry, 30(5), 269-276. https://doi.org/10.1007/3-540$\underline{27684-X \_18}$

Loomis, J., Kent, P and Strange, L. (2000). Measuring the total economic value of ecosystem services in an impaired river basin results from a contingent valuation survey. Ecological Economics, 33, $103-117$. https://doi.org/10.1016/s0921-8009(99)00131-7

McConnachie, M.M., Shackleton, C.M and McGregor, G.K. (2008). The extent of public green space and alien plant species in 10 small towns of the Sub-Tropical Thicket Biome, South Africa. Urban Forestry and Urban Greening, 7(1), 1-13. https://doi.org/10.1016/j.ufug.2007.12.003

Mensah, C.A. (2014). Urban green spaces in Africa: Nature and challenges. Ecosystem, 4(1), 1-11.

Millennium Ecosystem Assessment (2015). Ecosystems and human well-being: current state and trends. Island Press: Washington, DC, USA. 47.

Mpofu, T.P.Z. (2013). Environmental challenges of urbanization: a case study for open green space management. Agricultural and Environmental Management, 2(4), 105-110. 
NEST (1991). Nigeria's threatened environment: A National Profile.

Nowak, D.J., Hoehn, R.E., Bodine, A., Greenfield, E.J., Ellis, A., Endreny, T.A., Yang, Y., Zhou, T and Henry, R. (2016). Assessing urban forest effects and values: Toronto's urban forest. United States Department of Agriculture Forest Service, Northern Research Station Resource Bulletin. 14. https://doi.org/10.2737/nrs-rb-79

Odermerho, F.O. (1988). Benin City: a case study of urban floods. In: environmental issues and management in Nigerian development (P.O. Bada, O. Odemerho, eds.), Evans Brothers Publishers. 97-105.

Ogigirigi, M.A. (1986). Deforestation: its impact on the environment. Forestry Association of Nigeria Conference. $34-$ 46.

Oguntala, A.B. (1993). Forestry for urban and rural development in Nigeria with reference to urban environments. Forestry Association of Nigeria Conference. 1-10.

Olaleye, D.O., Ayoade, O.J and Omisore, E.O. (2013). A multivariate analysis of factors influencing green space provision in residential neighbourhood of Sub-Saharan African cities. Environment and Earth Science, 3(5), $138-146$.

Resende, F.M., Fernandes, G.W., Andrade, D.C and Néder, H.D. (2017). Economic valuation of the ecosystem services provided by a protected area in the Brazilian Cerrado: application of the contingent valuation method. Brazilian Journal of Biology, 2, 133-145. https://doi.org/10.1590/1519-6984.21215

Roberts, D., Boon, R., Diederichs, N., Douwes, E., Govender, N., McInnes, A., et al. (2012). Exploring ecosystembased adaptation in Durban, South Africa: "Learning-by-doing" at the local government coal face. Environment and Urbanization, 24(1), 167-195. https://doi.org/10.1177/0956247811431412

Sanderson, S.E and Redford, K.H. (2013). Contested relationships between biodiversity conservation and poverty alleviation. Oryx, 37, 389-390. https://doi.org/10.1017/s003060530300070x

Schroeder, H., Flannigan, J.K and Coles, R. (2006). Residents' attitudes toward street trees in the United Kingdom and United State communities. Arboriculture and Urban Forestry, 32(5), 236-246.

Schwab, J.C. (2009). Branching out: cities are learning the many benefits of urban forestry programs. Planning, 75, 1115 .

Simpson, R and Sedjo, R.A. (2006). Paying for the conservation of endangered ecosystems: a comparison of direct and indirect approaches. Environment and Development Economics, 1, 241-257. https://doi.org/10.1017/s1355770x00000607

United Nations (2015a). Resolution adopted by the General Assembly on 25 September 2015. 70/1. Transforming our world: the 2030 Agenda for Sustainable Development. United Nations (2015b). World urbanization prospects: The 2014 revision. Population Division: Department of Economic and Social Affairs.

United Nations Habitat (2014). The state of African cities: re-imagining sustainable urban transitions. Nairobi: UN Habitat.

Venter, Z. S., Shackleton, C. M., Van Staden, F., Selomane, O., \& Masterson, V. A. (2020). Green Apartheid: Urban green infrastructure remains unequally distributed across income and race geographies in South Africa. Landscape and Urban Planning, 203, 103889. https://doi.org/10.1016/j.landurbplan.2020.103889

Wolf, K.L., Blahna, D.J., Brinkley, W and Romolini, M. (2011). Environmental stewardship footprint research: linking human agency and ecosystem health in the Puget South region. Urban Ecosystem, 67, 12-18. https://doi.org/10.1007/s11252-011-0175-6

Yeshitela, K. (2020). Attitude and Perception of Residents towards the Benefits, Challenges and Quality of Neighborhood Parks in a Sub-Saharan Africa City. Land, 9(11), 450. https://doi.org/10.3390/land9110450

Zhang, B., Wang, W., He, X., Zhou, W., Xiao, L., Lv, H and Wei, C. (2017). Shading, cooling and humidifying effects of urban forests in Harbin city and possible association with various factors. Chinese Journal of Ecology, 36, 951-961.

Zhang, Y., Hussain, A., Deng, J and Letson, N. (2007b). Public attitudes toward urban trees and supporting urban tree programs. Environment and Behaviour, 39(6), 797-814. https://doi.org/10.1177/0013916506292326 


\section{DECLARATION OF CONTRIBUTIONS TO THE ARTICLE - - CRediT}

\begin{tabular}{|c|c|c|c|c|}
\hline ROLE & Arabomen & Babalola & Idumah & Ofordu \\
\hline $\begin{array}{l}\text { Conceptualization - Ideas; formulation or evolution of overarching research goals } \\
\text { and aims. }\end{array}$ & $\mathrm{X}$ & & & \\
\hline \multicolumn{5}{|l|}{$\begin{array}{l}\text { Data curation - Management activities to annotate (produce metadata), scrub data } \\
\text { and maintain research data (including software code, where it is necessary for } \\
\text { interpreting the data itself) for initial use and later re-use. }\end{array}$} \\
\hline $\begin{array}{l}\text { Formal analysis - Application of statistical, mathematical, computational, or other } \\
\text { formal techniques to analyze or synthesize study data. }\end{array}$ & $X$ & & & \\
\hline $\begin{array}{l}\text { Funding acquisition - Acquisition of the financial support for the project leading to } \\
\text { this publication. }\end{array}$ & $\mathrm{X}$ & & & \\
\hline $\begin{array}{l}\text { Investigation - Conducting a research and investigation process, specifically } \\
\text { performing the experiments, or data/evidence collection. }\end{array}$ & $\mathrm{X}$ & & & \\
\hline Methodology - Development or design of methodology; creation of models. & $\mathrm{X}$ & & & \\
\hline $\begin{array}{l}\text { Project administration - Management and coordination responsibility for the } \\
\text { research activity planning and execution. }\end{array}$ & & $X$ & & \\
\hline \multicolumn{5}{|l|}{$\begin{array}{l}\text { Resources - Provision of study materials, reagents, materials, patients, laboratory } \\
\text { samples, animals, instrumentation, computing resources, or other analysis tools. }\end{array}$} \\
\hline \multicolumn{5}{|l|}{$\begin{array}{l}\text { Software - Programming, software development; designing computer programs; } \\
\text { implementation of the computer code and supporting algorithms; testing of existing } \\
\text { code components. }\end{array}$} \\
\hline $\begin{array}{l}\text { Supervision - Oversight and leadership responsibility for the research activity } \\
\text { planning and execution, including mentorship external to the core team. }\end{array}$ & & $\mathrm{X}$ & & \\
\hline \multicolumn{5}{|l|}{$\begin{array}{l}\text { Validation - Verification, whether as a part of the activity or separate, of the overall } \\
\text { replication/reproducibility of results/experiments and other research outputs. }\end{array}$} \\
\hline \multicolumn{5}{|l|}{$\begin{array}{l}\text { Visualization - Preparation, creation and/or presentation of the published work, } \\
\text { specifically visualization/data presentation. }\end{array}$} \\
\hline $\begin{array}{l}\text { Writing - original draft - Preparation, creation and/or presentation of the published } \\
\text { work, specifically writing the initial draft (including substantive translation). }\end{array}$ & $\mathrm{X}$ & & & \\
\hline $\begin{array}{l}\text { Writing - review \& editing - Preparation, creation and/or presentation of the } \\
\text { published work by those from the original research group, specifically critical } \\
\text { review, commentary or revision - including pre- or post-publication stages. }\end{array}$ & & $X$ & $X$ & $\mathrm{X}$ \\
\hline
\end{tabular}

